\title{
NEED FOR STRUCTURE AND BIG FIVE PERSONALITY TRAITS AS PREDICTORS OF DECISION MAKING STYLES IN HEALTH PROFESSIONALS
}

\author{
Peter HALAMA, Jitka GURŇÁKOVÁ \\ Institute of Experimental Psychology, Slovak Academy of Sciences \\ Dúbravská cesta 9, 841 04, Bratislava, Slovak Republic \\ E-mail: peter.halama@savba.sk
}

\begin{abstract}
The study is focused on the question how the need for structure and the Big Five personality traits predict decision making styles in health professionals. The sample included 225 health care professionals from different areas (physicians, nurses, paramedics, emergency link operators). Need for structure was measured by Personal Need for Structure scale, Big Five Traits by Ten Item Personality Inventory, and the decision making styles by Melbourne Decision Making Questionnaire. The results showed that the best predictor of vigilance was need for structure, while extroversion was a negative predictor of non-vigilant styles. Analysis of interaction showed that neuroticism interacts with need for structure in prediction of non-vigilant decision making styles (hypervigilance, procrastination and buck-passing). Specifically, persons with low neuroticism and low need for structure tend to use more non-vigilant decision making styles in comparison to others.
\end{abstract}

Key words: decision making styles, need for structure, Big Five personality traits

Healthcare is one of the areas, where decision making processes play an important role. Health professionals make various decisions on a constant basis. These decisions are related to different matters, such as, the type of diagnostics or intervention, modification of the standard procedures or how make a treatment more effective (Halama, 2013). Very frequently, these decisions have serious outcomes and can result in possible financial or human harm. Gurňáková (2011), who reviews in detail the issue of decision making in health professionals, emphasizes that mistakes on the part of medical doctors are often serious and irreversible. Decision mak-

This work was supported by the Slovak Research and Development Agency under the contract No. APVV-0361-12. ing in the area of health care has specific features, which include complexity of the environment as well as the task itself. Hunink et al. (2001) adds to this, diagnostic and therapeutic uncertainty, patient preferences or cost issues as factors which makes decision making in this area more complicated. Chapman and Sonnerberg (2000) consider health care as a very specific area for investigation of decision making, because it includes such aspects as uncertainty of the results or multiplicity of attributes, the alternatives of which must be compared. There are two basic approaches to medical decision making. Normative approach in healthcare is mostly understood as application of Evidence Based Medicine (EBM) principles (Rosenberg, Donald, 1995), which includes clarification of the problem, searching for

DOI: $10.21909 / \mathrm{sp} .2014 .03 .658$ 
relevant clinical studies, evaluation of evidence related to individual alternatives as well as application of most validated options. On the other side, naturalistic approach to decision making in health care is oriented toward processes, which are applied in the face of less structured and multifaceted problems. This approach (Zsambok, 1997) focuses on professional decision making in complex situations, which are characterized by low structure, time pressure, and serious consequences and often by a dynamic and changing environment. It postulated several models, which describe the decision processes in such situations, as does the Recognition-Primed model (Klein, 1993, 1997), which emphasizes that the key process in such situations is not a comparison of alternatives, but searching for proper options based on past experiences. This process is time-saving and frequently used in many health care areas, such as emergency medicine, etc.

A decision making process is always an interaction between a situation in which a decision has to be made and the person, who makes the decision (Narayan, CorcoranPerry, 1997). Previous research has confirmed that personality is an important factor in decision making in different contexts, such as risky decision making in a laboratory (Lauriola, Levin, 2001), career decisions (Chartrand et al., 1993), etc. This is valid for the area of healthcare or health professionals as well. Pilárik and Sarmány-Schuller (2011) investigated paramedics and they found that the best predictors of good decision making in the Iowa Gambling test are low neuroticism and extraversion in males, and emotional awareness in females. Also, Kamhalová et al. (2013) found that subjectively good decisions of health profession- als are predicted by emotional regulations styles, especially by cognitive and behavioral engagement. These results suggest that personality characteristics can influence both cognitive and emotional processes involved in decision making of health care professionals.

As was mentioned above, decision making in health care professionals is characterized by low level of structuredness, which can present a problem for persons who need more structure in dealing with the environment. This personality characteristic is the subject of the psychological construct named personal need for structure. It is based on the assumption that people create structural representation of the outer and inner environment and try to categorize information into a meaningful structure. This reduction of information related to the environment can help with management and prediction of the world (Neuberg, Newsom, 1993). However, people differ in their need to create such structure. Personal need for structure is a personality characteristic, which describes individual differences in the tendency to actively seek and prefer simpler cognitive structures (Neuberg, Newsom, 1993). This tendency has two composites: desire for structure, which reflects a preference for structured information and environment in personal life, and reaction to lack of structure, which is related to the way people react when dealing with unstructured and unpredictable events. Previous research has shown that personal need for structure is related to many different aspects of cognitive processing, such as negative relation to creativity (Rietzschel et al., 2007), positive relation to perception rigidity (Sarmány Schuller, 2001) and authoritarianism (Jugert et al., 2009). However, this does not mean that personal 
need for structure is merely a negative personality characteristic. Neuberg and Newsom (1993) emphasized that reduction of the uncertain and unstructured environment is helpful with new demanding situation. For example, Vess et al. (2009) found that high score of personal need for structure is helpful when sustaining meaning in life after death-focused ideation.

In this study, we focused on the question of how personal need for structure and its dimensions (desire for structure and response to lack of structure) predict decision making styles in health care professionals. We assume that personal need for structure can be a factor in cognitive processing when dealing with problem situations, which are often low structured in the health care environment, and therefore it can predict styles of how individual health care professionals deal with problems. We also focus on the question concerning the way personality traits are involved in these relationships. Our analysis is aimed at simple correlations between the measured variables as well as possible interaction between the need for structure and personality traits in the prediction of decision making strategies, which could enlighten the possible influence of personality on these associations.

\section{METHOD}

\section{Sample}

The sample consisted of 225 health care professionals from different areas of expertise. 19 of them were doctors, 65 paramedics, 60 nurses, and 85 emergency link operators. Their mean age was 39.02 years. 58 of them were males and 165 females, 2 of them did not provide this data. The participants we recruited from different regions of Slovakia, especially through health institution and educational events.

\section{Measures}

Personal need for structure was measured by the Personal Need for Structure scale, which was created by Thompson et al. (in Neuberg, Newsom, 1993) and adapted into Slovak language by Sarmány Schuller (2001). It is a 12 items scale using a six-point response scale, with two dimensions named as Desire for Structure (DFS) and Response to Lack of Structure(RLS). Desire for structurereflects a preference for structured information and environment in personal life. Response to lack of structure is related to the way people react when dealing with unstructured and unpredictable events. The sum of both subscales forms the global score named Personal Need for Structure(PNS). The two-factor structure of the scale was confirmed by Sollár (2008), who found that a model with two correlated factors best fitted the data collected with Slovak participants.

For measuring the Big Five personality traits, we used the Ten Item Personality Inventory (TIPI), constructed by Gosling, Rentfrow and Swann (2003). It is a short selfreport measure, which was created through selection of adjectives from previous measures of the Big Five. The selection reflected content validity of the adjectives with the aim to cover all broadness of the specific trait. The inventory contains 10 items, adjective markers, two for each of the following traits: neuroticism $(\mathrm{N})$, extraversion $(\mathrm{E})$, openness to experiences $(\mathrm{O})$, agreeableness $(\mathrm{A})$, and conscientiousness (C). The items are answered on a 7-point scale (from Disagree strongly to Agree strongly). The authors 
provide information on psychometric properties, test-retest correlation of 0.80 after two weeks (average for all dimensions) and 0.72 after six weeks. Construct validity was proved by correlations with other Big Five measures, which ranged from 0.65 for openness to 0.80 for extraversion.

For measuring decision making styles, we used the Melbourne Decision Making Questionnaire $(M D M Q)$. This questionnaire reflects the conflict theory of decision making and was created by Mann et al.(1997). Current version of the questionnaire contains 22 items, which are answered on a 3-point scale from True for me to Not true for me. The questionnaire comprises four decision making styles. Vigilance (VGL) is related to the style, which includes clarification of objectives to be achieved by the decision, canvassing alternatives, search for relevant information, and assimilation of the information in an unbiased manner, and evaluation of alternatives carefullybeforemaking a choice. According to the conflict theory, vigilance is the only coping pattern that allows proper and rational decision making. When using the hypervigilance style(HVG), the decision maker searches frantically for a way out of the dilemma. Due to time pressure, the decision maker impulsively seizes upon hastily contrived solutions that seem topromise immediaterelief. Thefull range of consequences of the choice is overlooked because of emotional excitement, perseveration, and limited attention. On theother hand, buck-passing $(B P)$ includes attribution of responsibility for one's own decisions to another person or group with responsibility. It is also associated with hesitation in decision making. Finally, procrastination (PRO) means replacing high-priority actions with tasks of lower priority, or doing something from which one derives enjoyment, and thus putting offimportant taskstoa later time or not making a decision at all. Concerning psychometric properties, Mann etal.(1997)confirmed satisfactory reliability of each factor using Cronbach alpha (from 0.74 for procrastination to 0.87 for hypervigilance and buckpassing).

\section{RESULTS}

In order to analyse possible effect of gender on the results, we performed t-test comparison of gender differences in decision making styles. The results showed that there are no significant differences, so we concluded that male and female health care professionals do not differ in decision making styles. In the second step, we analyzed Pearson correlations between personal need for structure, Big Five personality traits and decision making styles. These correlations are presented in Table 1. As seen, both dimension of personal need of structure as well as the global score positively correlated with vigilance, but not with other dimensions of decision making (except for the low correlation reaction to lack of structure with hypervigilance and low negative correlation of desire for structure with procrastination). The dimensions of personal need for structure (DFS and RLS) had strong mutual correlation. Concerning the Big Five personality traits, they showed only small correlations with decision making styles and although some of them were statistically significant, all were less than 0.2 , which is the reason why we do not comment on them. Concerning other correlations, there are strong correlations between three non-vigilant dimensions of decision making (hypervigilance, buck-passing, procrastination), which suggests that these variables can be saturated by a common factor. 
Table 1. Correlations between personal need for structure, Big Five personality traits and decision making styles

\begin{tabular}{|l|c|c|c|c|c|c|c|c|c|c|c|}
\hline & RLS & PNS & $\mathrm{N}$ & $\mathrm{E}$ & $\mathrm{O}$ & $\mathrm{A}$ & $\mathrm{C}$ & $\mathrm{VG}$ & HVG & BP & PRO \\
\hline DFS & $0.549^{* *}$ & $0.855^{* *}$ & -0.102 & $0.222^{* *}$ & 0.104 & 0.028 & 0.061 & $0.265^{* *}$ & 0.063 & -0.085 & $-0.156^{*}$ \\
\hline RLS & & $0.903^{* *}$ & $-0.188^{* *}$ & 0.084 & -0.035 & -0.071 & -0.035 & $0.266^{* *}$ & $0.186^{* *}$ & 0.042 & -0.074 \\
\hline PNS & & & $-0.157^{*}$ & $0.170^{*}$ & -0.040 & -0.040 & 0.018 & $0.276^{* *}$ & 0.135 & -0.037 & -0.128 \\
\hline N & & & & $-0.246^{* *}$ & -0.064 & -0.090 & 0.125 & 0.022 & -0.127 & -0.041 & -0.011 \\
\hline E & & & & & $0.165^{*}$ & 0.087 & 0.013 & -0.012 & $-0.184^{* *}$ & $-0.155^{*}$ & $-0.196^{* *}$ \\
\hline O & & & & & & 0.131 & $0.174^{*}$ & -0.050 & $0.149^{*}$ & $0.157^{*}$ & 0.005 \\
\hline A & & & & & & & $0.316^{* *}$ & 0.104 & 0.051 & -0.017 & -0.137 \\
\hline C & & & & & & & & -0.012 & 0.001 & -0.033 & -0.020 \\
\hline VG & & & & & & & & & 0.070 & 0.058 & $-0.174^{*}$ \\
\hline HVG & & & & & & & & & & $0.587^{* *}$ & $0.581^{* *}$ \\
\hline BP & & & & & & & & & & & $0.500^{* *}$ \\
\hline
\end{tabular}

Note: DFS - desire for structure, RLS - response to lack of structure, PNS - personal need for structure, N - neuroticism, $\mathrm{E}$ - extraversion, $\mathrm{O}$ - openness, A - agreeableness, C-conscientiousness, VG-vigilance, HVG-hypervigilance, $\mathrm{BP}$ - buck-passing, $\mathrm{PRO}$ - procrastination

$* \mathrm{p} \leq 0.05, * * \mathrm{p} \leq 0.01$

In the next step, we analyzed the interaction of personal need for structure and personality traits in the prediction of decision making styles. For this purpose, we used moderation analysis on the base of hierarchical regression analysis, which uses an interaction term computed as the product of both interacting variables (Aiken, West, 1991). Interacting variables were centered by a mean in order to reduce the multicolinearity problem. To reduce the number of analyses, we used only the global score PNS as the dependent variable. Also, high correlations between three non-vigilant decision making styles (hypervigilance, buck-passing, procrastination) gave us a reason to integrate them into one variable. We did this through factor analysis, based on the principal component method with saving the regression score of individual persons as the variable. This variable was named non-vigilant decision making style. Together we conducted ten analyses (every trait with vigilance and also with non-vigilant decision making style).
Only one of these analyses revealed significant interaction, specifically interaction of neuroticism and need for structure in predicting non-vigilant decision making style. Table 2 presents the results of this analysis. As seen, the interaction term in the second step shows significant level of t-value, what indicates an interaction between predictors. Figure 1 presents graphical projection of the interaction effect. The points represent individual respondents and their location corresponds with their values of need for structure and non-vigilant decision making style. The lines represent regression lines of the relationship between need for structure and non-vigilant ways of coping in two groups of people with high and low neuroticism. The lines differ in their direction. People with high neuroticism show a positive relationship between need for structure and non-vigilant decision making styles. On the other hand, people with low neuroticism show a negative relationship between need for structure and non-vigilant decision making styles. 
Table 2. Hierarchical regression analysis testing the interaction between neuroticism and personal need for structure in prediction of non-vigilant decision making styles

\begin{tabular}{|l|c|c|c|c|}
\hline & $\mathrm{B}$ & St. error & Beta & $\mathrm{t}$-value \\
\hline 1st step & & & & \\
\hline need for structure & -0.004 & 0.010 & -0.028 & -0.364 \\
\hline neuroticism & -0.053 & 0.039 & -0.103 & -1.358 \\
\hline 2nd step & & & & \\
\hline need for structure & -0.003 & 0.010 & -0.024 & -0.319 \\
\hline neuroticism & -0.059 & 0.039 & -0.115 & -1.535 \\
\hline need for structure x neuroticism & 0.012 & 0.005 & 0.194 & $2.616^{* *}$ \\
\hline
\end{tabular}

$* * \mathrm{p}<0.01$

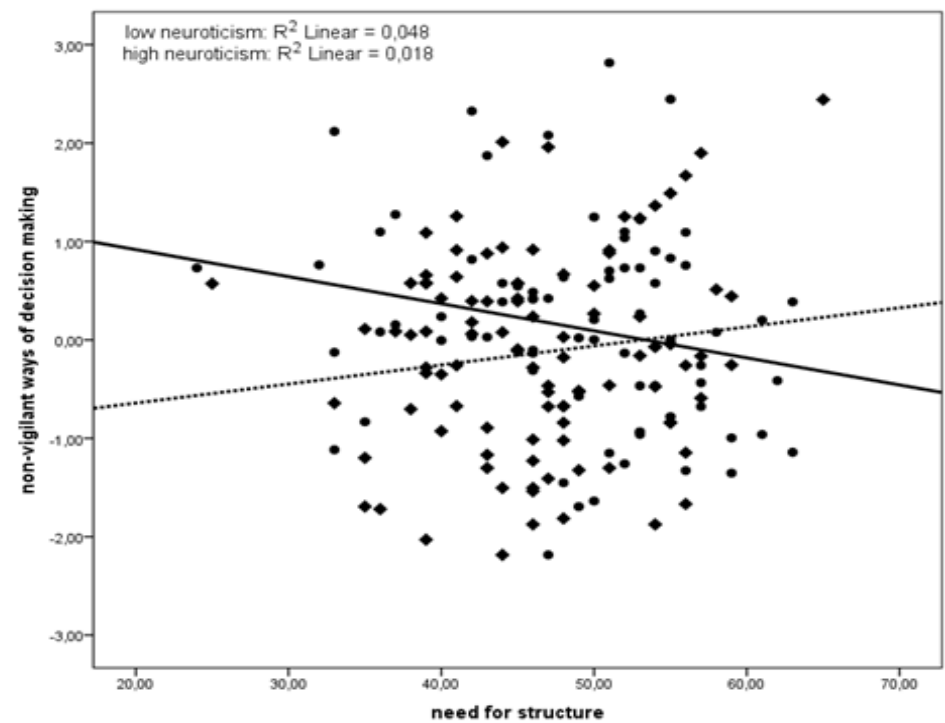

low neuroticism high neuroticism -... high neuroticism

Figure 1. Graphical representation of the interaction between neuroticism and need for structure in prediction of non-vigilant styles of decision making

\section{DISCUSSION}

The correlation analysis revealed several significant relationships between personal need for structure and decision making styles. Especially, both dimensions as well as global score of PNS correlated positively with vigilance, which is considered among the constructive decision making styles, in other words, as decision making styles leading to proper and rational decision making 
(Mann et al., 1997). In this case, personal need for structure seems to be a positive characteristic, which encourages a vigilant approach to the situation of decision making. Although previous research found that personal need for structure can be related to rigidity or low creativeness (Rietzschel et al., 2007; Sarmány Schuller, 2001), the special nature of making health care decisions could be the reason why this is not the case in these conditions. As it was mentioned above, health care decision making is characterized especially by low structure, time pressure and serious consequences. To make a rational and good decision means to develop adequate structure, which enables proper comprehension of the situation and factors affecting the next consequences. As Klein $(1993,1997)$ suggested in his RecognitionPrimed model, this structure is, to a great extent, based on previous experiences with similar situations. In these conditions, higher level of need for structure can be a source of motivation to start and continue the process of developing a cognitive structure. People with low level of need for structure can fail in this process, as they are lacking motivation for developing a structure. As an outcome, lack of structure causes lack of motivation for vigilant approach to a problem, especially canvassing alternatives, searching for relevant information, and careful evaluation of alternatives (Mann et al., 1997). Therefore, we think that motivational consequences of need for structure are responsible for positive relationship between PNS and vigilance in this sample. Our results suggest, that in low structured environment, high level of personal need for structure can be a motivational source of tendency to deal constructively with a problem and it can positively contribute to making proper decisions.
On the other hand, personal need for structure correlated with other decision making styles only occasionally and at very low level. There were only two significant correlations (positive correlation between reaction to lack of structure and negative correlation between desire for structure and procrastination) but they were too small (less than 0.2) and did not suggest consistent tendency. From the Big Five personality traits, only extraversion showed more consistency in the correlations pattern. This trait had significant negative correlation with all non-vigilant decision making styles as hypervigilance, buck-passing and procrastination. It seems that higher level of extraversion can work as a protective factor towards non-vigilant ways of decision making. We think that this could be especially due to its content, which includes not only sociability but also vitality, vigorousity, etc. (e.g., John, Naumann, Soto, 2008), in the method used in this study this is represented by the adjective 'enthusiastic' (Gosling, Rentfrow, Swann, 2003). High level of extraversion could be functioning as a source for investment of energy into processing the situation and as a prevention against using non-constructive ways of coping with a problem. On the other hand, as is suggested by the low size of the correlations, extraversion should be considered only as one of the many factors in this process.

Interaction analysis revealed only one significant interaction between personality traits and need for structure in the prediction of decision making styles, specifically, interaction between neuroticism and need for structure in the prediction of non-vigilant decision making styles. As seen in Figure 1 , this interaction shows cross-line type of moderation, which means that the regression lines have the opposite direction. This 
means, that people with high and low neuroticism differ in the direction of the relationship between need for structure and use of non-vigilant decision making styles. In people with high neuroticism, the relationship between need for structure and nonvigilant decision making styles shows a positive direction. This suggests that in these persons, higher level of need for structure tends to increase this type of behavior related to decision making. On the other hand, the direction of the relationship between need for structure and non-vigilant decision making is negative in persons with low level of neuroticism. This means that in this group, personal need for structure reduces a level of non-vigilant decision making behavior. Although this result could seem contradictory at first, we think that it is a good illustration of the fact discussed above. Personal need for structure has both negative (e.g., Rietzschel et al., 2007; Sarmány Schuller, 2001) as well as positive (e.g., Neuberg, Newsom, 1993; Vess et al., 2009) effect on human functioning. Our results suggest, that positive or negative effect of need for structure depends not only on specific variables, which need for structure is related to, but also on the personality characteristics of the individual and the context of research. In low structured situations, such as health care decision making, personal need for structure can have a double effect. In neurotic people, which are characterized by high level of negative emotions (Gosling, Rentfrow, Swann, 2003), lack of structure in combination with high need for structure can evoke anxiety related to a situation and subsequently increase negative decision making behavior. On the other hand, in emotionally stable people, the same combination can lead to the effort to de- velop a proper structure, which is expressed in high score of vigilance.

\section{CONCLUSION}

To conclude, our results support the assumption, that personal need for structure predicts decision making styles in health care professionals, although we found that only vigilance had consistent relationships with personal need for structure. We did not discover consistent relationships of the Big Five personality traits with the exception of extraversion, which at low level is negatively related to non-vigilant styles of decision making. However, our results suggest, that some of the traits (in our case neuroticism) can interact with other personality characteristics in the prediction of decision making processes. Therefore, we think that further research should not only focus on simple relationships between decision making and personality variables, but on multivariate analysis of variables, which can bring more detailed and thorough findings related to this area.

Received March 19, 2014

\section{REFERENCES}

AIKEN, L.S., WEST, S.G., 1991, Multiple regression: Testing and interpreting interaction. Thousand Oaks: Sage.

CHAPMAN, G.B., SONNENBERG, F.A., 2000, Decision making in health carwe. Theory, psychology and applications. Cambridge: Cambridge University Press.

CHARTRAND, J.M., ROSE, M.L., ELLIOTT, T.R., MARMAROSH, C., CALDWELL, S., 1993, Peeling back the onion: Personality, problem solving, and career decision-making style correlates of career indecision. Journal of Career Assessment, 1, 66-82. 
GOSLING, S.D., RENTFROW, P.J., SWANN W.B., 2003, A very brief measure of the Big-Five personality domains. Journal of Research in Personality, 37, 504-528.

GURŇÁKOVÁ, J., 2011, Rozhodovanie v praxi. Prehl'ad výskumov naturalistického rozhodovania v oblasti poskytovania zdravotnej starostlivosti [Decision making in practice. Review of naturalistic decision making research in the area of health care]. In: J. Gurňáková a kol., Úvod do naturalistického rozhodovania (pp. 161-190). Bratislava: Ústav experimentálnej psychológie SAV.

HALAMA, P., 2013, Pät' vel'kých faktorov osobnosti ako prediktory vnímanej efektivity rozhodovania zdravotníckych profesionálov. [Big five personality traits as predictors of subjective decision making effectiveness in health proffesionals]. In: J. Gurňáková a kol., Rozhodovanie profesionálov: Sebaregulácia, stres a osobnost' (pp. 191-184). Bratislava: Ústav experimentálnej psychológie SAV.

HUNINK, M.G.M., GLASZIOU, P.P., SIEGEL, J.E., WEEKS, J.C., PLISKIN, J.S., ELSTEIN, A.S., WEINSTEIN, M.C., 2001, Decision making in health and medicine. Integrating evidence and values. Cambridge: Cambridge University Press.

JOHN, O.P., NAUMANN, L.P., SOTO, C.J., 2008, Paradigm shift to the integrative Big Five trait taxonomy: History, measurement, and conceptual issues. In: O.P. John, R.W. Robins, L.A. Pervin (Eds.), Handbook of personality: Theory and research (pp. 114-158). New York: Guilford.

JUGERT, P., COHRS, J.C., DUCKITT, J., 2009 Inter and intrapersonal processes underlying authoritarianism: The role of social conformity and personal need for structure. European Journal of Personality, 23, 607-621.

KAMHALOVÁ, I., HALAMA, P., GURŇÁKOVÁ, J., 2013, Affect regulation and decision making in health-care professionals: Typology approach. Studia Psychologica, 55, 19-31.

KLEIN, G., 1993, A recognition primed decision (RPD) model of rapid decision making. In: G.A Klein, J. Orasanu, R. Calderwood, C. Zsambok (Eds.), Decision making in action: Models and methods (pp. 138-147). Norwood, NJ: Alex.

KLEIN, G., 1997, The recognition-primed model: Looking back, looping forward. In: C. Zsambok, G. Klein (Eds.), Naturalistic decision making (pp. 285292). Hillsdale, NJ: Erlbaum.
LAURIOLA, M., LEVIN, I.P., 2001, Personality traits and risky decision-making in a controlled experimental task: An exploratory study. Personality and Individual Differences, 31, 215226.

MANN, L., BURNETT, P., RADFORD, M., FORD, S., 1997, The Melbourne Decision Making Questionnaire: An instrument for measuring patterns for coping with decisional conflict, Journal of Decision Making, 10, 1-19.

NARAYAN, S.M., CORCORAN-PERRY, S., 1997, Line of reasoning as a representation of nurses clinical decision making. Research in Nursing and Health, 20, 353-364.

NEUBERG, S.L., NEWSOM, J.T., 1993, Personal need for structure: Individual differences in the desire for simpler structure. Journal of Personality and Social Psychology, 65, 113-131.

PILÁRIK, L., SARMÁNY-SCHULER, I., 2011, Personality predictors of decision-making of medical rescuers. Studia Psychologica, 53, 175-184.

RIETZSCHEL, E.F., DE DREU, C.K.W., NIJSTAD, B.A., 2007, Need for structure and creative performance: The moderating role of fear of invalidity. Personality and Social Psychology Bulletin, 33, 855-866.

ROSENBERG, W., DONALD, A., 1995, Evidence based medicine: An approach to clinical problem-solving. British Medical Journal, 310, 1122-1126.

SARMÁNY SCHULlER, I., 2001, Potreba štruktúry a schopnost' vytvárania štruktúry ako osobnostné konštrukty [Need for structure and ability to make structure as personality constructs]. In: I. Sarmány Schuller (Ed.), Psychológia pre bezpečný svet (pp. 336-339). Bratislava: Stimul.

SOLLÁR, T., 2008, Need for structure from a theoretical and methodological perspective. Studia Psychologica, 50, 277-289.

VESS, M., ARNDT, J., COX, C.R., ROUTLEDGE, C., GOLDENBERG, J.L., 2009, The terror management of medical decisions: The effect of mortality salience and religious fundamentalism on support for faith-based medical intervention. Journal of Personality and Social Psychology, 97, 334-350.

ZSAMBOK, C.E., 1997, Naturalistic decision making. Where we are now? In: C.E. Zsambok, G. Klein (Eds.), Naturalistic decision making (pp. 316). Mahwah: Lawrence Erlbaum. 


\title{
POTREBA ŠTRUKTÚRY A PÄŤ VELKÝCH OSOBNOSTNÝCH ČŔT AKO PREDIKTORY ROZHODOVACÍCH ŠTÝLOV U ZDRAVOTNÍCKYCH PROFESIONÁLOV
}

\author{
P. H a 1 a m a, J. G u r n̆á k o vá
}

Súhrn: Štúdia sa zameriava na otázku, ako potreba štruktúry a pät' vel'kých osobnostných čŕt predikuje rozhodovacie štýly u zdravotníckych profesionálov. Výskumný výber zahŕňal 225 zdravotníckych pracovníkov z rôznych oblastí (lekári, zdravotné sestry, záchranári, operátori pohotovostných liniek). Potreba štruktúry bola meraná Škálou osobnej potreby štruktúry, pät’ osobnostných čŕt Desatpoložkovým osobnostným inventárom a rozhodovacie štýly Melbournským dotazníkom rozhodovania. Výsledky ukázali, že najlepším prediktorom vigilancie je potreba šruktúry, kým extroverzia je prediktorom nevigilantných štýlov. Analýza interakcií ukázala, že neurotizmus interaguje s potrebou štruktúry pri predikcii nevigilantných rozhodovacích štýlov (hypervigilancia, prokrastinácia, presúvanie zodpovednosti), konkrétne osoby s nízkym neurotizmom a nízkou potrebou štruktúry majú tendenciu používat' viac nevigilantné rozhodovacie štýly oproti ostatným. 